\title{
Deforestation across the World: Causes and Alternatives for Mitigating
}

\author{
Alexandre Marco da Silva and John Rodgers
}

\begin{abstract}
We underline the main causes of deforestation and present a framework for mitigating the continual loss of forest habitat around the world. The causes of deforestation are complex and they operate at multiple spatial and temporal scales, yet they are related to societal and political factors. Societal factors consist of human migration within rural settings and poverty. Political factors include ineffective land management and negligence of monitoring and protecting forest commodities. Combined, these factors present arduous challenges to protecting forest habitats. In turn, there are at least three strategies to reduce further forest loss. The first strategy involves the cessation of timber cutting and extraction of other forest products. But just as important is the second strategy of creating and maintaining more Environmental Protected Areas. The third strategy is perhaps the greatest challenge, and it involves the adoption of the "green nudge principle", whereby individuals are educated to modify individual behaviors related to patterns of consumption and to the conservation of remaining forests. This is especially true for the increasingly endangered primary forests. An adoption of these mitigation strategies will help reduce deforestation and will help improve global environments.
\end{abstract}

Index Terms-Biodiversity, forests, governance, natural resources conservation.

\section{INTRODUCTION}

Humans have cleared forests for centuries, however, since the mid Twentieth Century, the rate of forest clearing increased exponentially. The enormous amount of world-wide forest clearing caught the attention of both researchers and the public. The heightened awareness of forest loss promoted the term 'deforestation', which is defined as the alteration of the forest into non-forested land cover classes, such as agriculture, pasture, and built-up landscapes. It is widely accepted that deforestation causes loss of biodiversity and several other environmental injuries [1].

It is generally recognized that deforestation is strongly related to human population growth and to the increasing complexity of human societies. Researchers have explored the causes of deforestation [2]-[4] and many attempts have been made to explain these phenomena. Different approaches at multiple scales have been developed to help minimize and abate deforestation worldwide [5]-[8].

Although the causes of deforestation may not be all clear,

Manuscript received August 21, 2017; revised September 30, 2017.

Alexandre Marco da Silva is with Institute of Science and Technology of Sorocaba, São Paulo State University, Brazil (email: amsilva@sorocaba.unesp.br).

John Rodgers is with the Department of Geosciences, Mississippi State University, USA (email: rodgers@geosci.msstate.edu). proposals to mitigate the loss of forest are often excessively specific. A systematic literature review may help integrate and summarize what is known about this topic. Therefore a literature review was conducted to address the human-based causes of deforestation worldwide. Based on this review of the literature, alternative conservation ideas are postulated for mitigating deforestation on a global scale.

\section{A General VIEW}

\section{A. The Concept of Forest Areas and Rates of Deforestation}

Forest area can be considered as natural or planted sets of trees of at least 5 meters in the locus, irrespective of whether it is productive or not [9]. This definition of forest area excludes tree sets in systems of agricultural production (e.g., in agro-forestry and fruit plantations systems) as well as trees in urban parks and gardens [9].

Forested areas constitute one of the most important ecosystems for humans because of their many social, economic, educational, and scientific values. The majority of the world's human population is either directly or indirectly connected to forests because forests provide sources of materials, create employment opportunities through forest-based industries, or offer other types of relationships [10]. In 2012 there were $39,430,117 \mathrm{~km}^{2}$ of forested area (31.0\% of total land) [9] and four countries provided $48.3 \%$ of this total: Brazil, Canada, The Russian Federation, and The United States of America.

Intact or primary forests constitute one of the most important ecological infrastructures [11], especially because they provide a number of land-based ecosystem services, such as air-quality regulation, nutrient cycling, carbon sequestration, pollination, disease control, freshwater provision, shelter provision, storm protection, water-quality regulation [12]-[14]. They are irreplaceable ecosystems, and any attempts to substitute them would be prohibitively expensive and would not be worth the cost [15]. Secondary forests also supply ecosystem services that are of value, but secondary forests are neither equal to nor a substitute for the values provided by primary forests [14].

An important factor regarding the quality of forest is the area of intact or contiguous forest patches. The concept of large intact forest landscapes or truly undisturbed forest is "an unbroken expanse of natural ecosystems within areas of existing forest extent, without signs of major human activity, with a minimal area of $500 \mathrm{~km}^{2}$ " [11]. From 2000 - 2012, this type of forest comprised 13.1 million square kilometers [12] and corresponded to approximately $33 \%$ of the total forested area. 
Based on data proved by World Bank [9], it is estimated that from 2000 to 2012, the average annual deforestation rate was $0.12 \%$. For such period over $40 \%$ of the world's countries lost forested area totaling $1,036,998 \mathrm{~km}^{2}$ of deforestation. Twenty-five percent of the countries showed no change in forest cover and only $30 \%$ of countries reported a net increase in forested area, totaling only $503.6 \mathrm{~km}^{2}$ of reforestation. This means that for each square kilometer of afforestation there were approximately $2.05 \mathrm{~km}^{2}$ of deforestation. In 2000 there was a worldwide average of $6,700 \mathrm{~m}^{2}$ per capita forested [9]. The value has decreased since then, and in 2012 this value was reduced to only 5,600 $\mathrm{m}^{2}$ per capita, which is considered by experts to be an alarming depreciation [16]. The reduction of the forest at this global scale cannot be fully explained by human population growth alone [8].

\section{B. Factors That Drive Deforestation}

Deforestation is still an on-going reality for most of the world, and it results from a complex interaction of direct and indirect factors. Migration, poverty, regional disparities in services, and reduced land delivery systems are key factors contributing to the intensity and shape of deforestation. Migration occurs at a rapid temporal scale because it operates at a much faster rate than vegetative growth. Migration is considered the major contributor to rapid population growth [17].

After the migrants settle to a host area, their population growth becomes increasingly important at the site level. Although the local, original inhabitants may not always be dedicated to conservation, they generally have a stronger connection with the land than the new diaspora. The locals can be considered "sons of the land", and they behave predominantly as long-term users of the available natural resources of the region [18]. Incoming migrants, on the other hand, are not as strongly tied to the land and are new to the ecosystem, thus they generally behave as explorers.

The modality of the "rural to rural" migration type has the greatest impact on local biodiversity [17]. In contrast to having no migrants or having migrants that move to urban regions, rural-frontier migrants are usually poorer, have a low educational level and have less local wage-labour experience [19]. Many migrants carry out the modality of shifting cultivation or ranching. Such people are searching for employment, whether in other rural areas, towns, cities, or abroad, and they remove themselves from the deforestation cycle (except as consumers) unless they join the very small part of laborers in the wood or cattle industry [20].

Usually, migrants have neither an affectionate relation with that settled land nor have the indigenous knowledge of the new place of residence because they are not from the area. Migrants may not see themselves as an element of the environment and they are not as attached to the forest area. Additionally, migration brings to the forest edge areas a more abundant supply of laborers, which ultimately diminishes worker wages. The over-abundance of laborers and the ensuing lowered wages at the forest edge, in turn, tends to increases profitability of agricultural production and leads to further land clearing and deforestation [21].

Landowners of forest areas typically engage in small-scale farming activities, including general farming and cattle ranching. The most common type of general farming is crop production that is operated on an economic budget without the use of expensive fertilizers. Cattle grazing, however, is generally considered to provide a higher profit margin because of lower labor inputs and a more stable market, however, overgrazing and subsequent land depreciation are exceptionally common [1]. With either general farming or cattle grazing, landowners typically do not have the financial resources to carefully and selectively clear forest patches. Instead, they slash and burn to clear the land [22], [23]. After the cleared land becomes less productive, the area experiences passive and unassisted revegetation of the forest. This leads to a rebuilding of ecological function through the slow improvement of soil quality and the increasing complexity of species assemblages and their ecological interactions [2], [22], [23].

Generally, land cover transformation occurs very quickly within the order of weeks or months. After a few months or up to a few years of exploration of the novel environment, and after the new land has been explored, the occupants (usually immigrants) are faced with at least three options to address the lack of land fertility: (a) abandon the altered area and seek new land because agricultural yield become unprofitable; (b) learn to adapt to the lesser conditions in the degraded land; or (c) input resources to revert the degradation process. The latter is associated with the afforestation process.

Agro-business has expanded into cleared forest areas by increasing large-scale mechanization, by incrementing the farm productivity, and by contributing to the acceleration of land cover change. Especially within tropical regions, private agricultural enterprises are increasingly exporting forest products to international markets [24], [25]. In some regions, deforestation is promoted by enterprises with local government authorization to use the land for agriculture. Even still, it is interesting that the cattle ranchers and farmers usually affirm that they are not personally responsible for deforestation [24], [26]. Timber is quickly removed.

Urban sprawl is another factor that drives the loss of forested areas [27] because the urban population and urban structures have increased substantially worldwide. For built-up landscapes to expand into forested areas the land clearing requires large investments of labor and effort [28]. A developer or a small group of developers starts the deforestation process usually within a frontier clearing region [29] because it is more economical to acquire land. The "limits" of the city expand toward the adjacent rural landscapes [30]. Physical features, such as topography, have an important influence on urban expansion because flat regions facilitate development, but hilly regions present more obstacles to construction.

It is generally accepted that forested areas located in steep terrains will not be of interest to developers, and these areas have low or non-existent market value [31]. However, these areas might still be damaged indirectly by urbanization, especially in locals where the urban expansion is poorly regulated by governments. In particular, the contiguity of forest patches is reduced and the overall habitat quality diminishes. When agricultural or grazing land is already 
present within flat areas, it is relatively easy for urban developers to acquire these lands. Provision of these services is simple; hence the land can easily and rapidly be urbanized. The land thereby gets a commercial value and comes onto the formal property market.

Another important factor that contributes to deforestation is the construction or expansion of transportation routes. Construction of roadways and rail lines damages ecosystems and reconfigure local landforms [32]. Valuable commodities such as logs, minerals, oil, and arable land often provide the economic impetus for initial road construction [33]. Due to the expansion of the road, network forest patches became more regularly shaped and linear [34].

Mining and construction of hydroelectric dams are also relevant activities in some locations in terms of importance for deforestation [3]. In areas subjected to mining, the combined use of sawmills and tractors promote the cleaning of the land. In many cases, the use of such equipment to clear land is neither well regulated nor inspected by governmental institutions. These activities play such an important role in the deforesting process because they need a lot of space (terrain) and they need to physically clear the forests. Because the demand for space (terrain) all trees are removed without a selection of the species of trees.

However, forests are also being damaged due over-exploration of resources, such as taking timber, seeds, hunting, and other materials provided by forests. This kind of exploration does not always result in deforestation. Selective explorations of species with high commercial value are harvested while species with non-commercial value are left alone. Even still, materials are illegally removed and there are no criteria, guidelines, or plans to replant or restore after harvesting [29]. The incentive to cut forest comes from the economic necessity for employment, for example within sawmills. Although it is intended to selectively remove timbers with the highest economic value, instead the market incentivizes large areas being cleared with much smaller and younger trees getting damaged or killed.

In many cases, the cut timber is often exported as raw logs providing only limited employments and/or limited profits for the local communities. In many tropical countries especially, deforestation has occurred very quickly as these countries attempt to expand economically. But it is generally known that economic forces often undermine their ability to cut forest sustainably. Government officials often have a strong influence on this process because they regulate the inspection of the exportation of materials. Further, for complicating the situation, many tropical countries also illegal import forest products, such as timber [34].

\section{Deforestation Mitigation AND A FRAMEWORK FOR MAINTAINING FOREST INTEGRITY}

We are dependent on forest areas as a society. Paradoxically we are still permitting, either directly or indirectly, the disappearance of these ecosystems. Changes in forest extent and quality raise concerns about biodiversity and global climate alterations [4]. It is important to keep in mind that there exist management practices that could make use of forests without totally destroying them. Approaches intermediated by government agencies have been developed to limit deforestation through economic incentives. Some examples where government attempts to limit deforestation occur through policies associate with property rights, economic valuation and market systems, fiscal apparatuses, support of livelihood, and financial supporting, and also payments for ecosystem services [13], [35].

It should be recognized that none of these approaches alone could stop deforestation. Integrated actions considering multiple geographic scales and multiple ecological dimensions for controlling the deforestation might provide a stronger and better approach to promoting local institutions and their involvement with the sustainability of the forests [29], [36].

\section{A. Government Initiatives for Monitoring Illegal Timber Trade}

Relationships among governments at the international level need to consider plans that regulate local and global demand for commodities, improve strategies for monitoring timber trade, and reduce the level of wood exploration by and exportation to other countries [6]. The majority of national governments are fervent supporters of international agreements in banning the traffic of timber and other forest products illegally logged, but as yet, they have not followed up on that agreement and have not produced efficient initiatives [35]. Planning could, for instance, positively change the attitudes of policy makers towards biodiversity and conservation [37].

An improved database system for tracking harvested forest material exports and imports and for tracking the distribution of forest products either shipped through harbors or transported along highways would be a promising technological contribution towards the solution of the problem [38]. Certified forest management initiatives are market-driven processes that have gained widespread acceptance [39]. These management ideas were introduced in the early 1990s to address alarms regarding the deforestation and forest degradation to promote the maintenance of the biodiversity [40].

\section{B. Extraction of Non Timber Forest Products and Non-wood Forest Products as a Profitable Way of Use of the Forests}

Local landowners or homeowners have alternatives to receive financial gain from forested ecosystems, and simultaneously this can help with their conservation. One such alternative is the exploration of non-timber forest and non-wood forest products (respectively, NTFP and NWFP). The NTFPs constitute all biological resources, other than timber, which are extracted from forested areas for human utilization [41]. The NTFPs are not necessarily within an ecological context, but instead, they are a set of products that are of economic interest. These materials illustrate the importance of forests other than just being a source for wood [7].

Some plant species have the potential to be explored as NTFP and NWFP, including ornamental plants, medicines, foods, and fibbers. However, people do not always appropriately utilize these species because they are not always readily abundant [41], [42]. The profitable potential 
for the utilization of NTFP depends decisively on the allocation of potentially useful species in different eco-regions.

There are important ecological circumstances that need to be considered when utilizing NTFPs. One consideration is never collecting large amounts of any NTFP from one single area, especially from a single species. The evident reason for this is that it avoids the over-exploration of a single product, which ultimately leads to an unbalanced forest ecosystem. Secondly, it is also crucial to avoid collecting products from endangered species because they are already under considerable pressure. It should be noted that achieving sustainability of collecting NTFP has to occur through public awareness of the importance of biodiversity and the environmental consequences of species extinctions, whether local extinctions or global ones. The third ecological consideration is that all NTFP-related work must be legalized in order to minimize smuggling of explored products.

\section{The Creation and Maintenance of Environmentally Protected Areas (EPAs)}

The creation of environmentally protected areas (hereafter EPA) is a logical alternative for conserving biodiversity and other local or regional ecosystems services [42], [43]. Presently, the global total land registered as environmentally protected areas represents only about $13 \%$. The world's leading economic governments have agreed to expand this value to $17 \%$ of the global land surface by 2020 to avoid the further loss of endangered species [44]. However, only a small fraction of this newly planned EPA has been established for primary forests.

The establishment of more EPAs provides global advantages for biodiversity and ecosystem services, yet these efforts have been criticized by some experts. It is held by dissenters that EPAs generate deterrents to conservation in addition to attractors to conservation [45]. As a consequence, it is not uncommon that environment problems, such as from burning, hunting, and logging still persist in many EPAs. Further, many EPA's are increasingly becoming surrounded by intensification of land use in the surrounding region even after they were implemented [45].

Some important considerations related to creation of EPA are: i) the bounding land cover types that border EPA's; ii) the minimal area of EPA for successfully maintain the ecological functions and structure, which are not static through time, and iii) the effective goal of the creation of the EPA and the rules of land cover of the buffer zone of the EPA.

EPAs already in existence have not been as successful in conserving species as originally expected because basic knowledge on forest productivity and ecological functions are missing. Thus it is challenging to develop effective management strategies. Many EPAs do not yet have a clear and definitive boundary, few of them have been designed to consider ecological interactions, and most of EPAs are located and shaped according to human use or scenic beauty rather than according to ecological functionality [27].

The percentage of areas destined to be EPA is below the intended 20\% [9], [12], [43]. Hence, EPAs need to be created, and the criteria for the establishment of new EPAs should be carefully developed in terms of location, area, and shape, in order to be effective. One possible option to detecting suitable areas for establishing a new EPA, in terms of the amount of space, is surveying what are the more complex species that live in the area, i.e., apply the "top-down" system of analysis. For example, it is important to recognize the habits of large animals that require large patches of the continuous area [46]. After evaluating the optimal area for such species, more information exists to establish the EPA minimal boundaries that will be the most effective at preserving forest habitat. If the area designated to be an EPA is suitable for the keystone species, then it would similarly be suitable for species with less complex habitat requirements. However, the geometrical shape of the forest fragment destined to be EPA(s) must also be considered because of the edge effect. An inefficient EPA geometry or boundary, irrespective of the area of extent, might jeopardize local biodiversity patterns. Table I presents a few alternatives that may be more effective.

TABLE I: EXPECTED DIFFERENCES OF THE EFFECTIVENESS ACCORDING TO THE FEATURES OF THE FRAGMENTS OF PROTECTED FOREST (DARK GREEN) AND OF PRODUCTION FOREST (SOFT GREEN) THAT MAY HELP TO CONSERVE THE BIODIVERSITY

\begin{tabular}{|c|c|c|c|c|}
\hline Efficacy & Size & Shape & Connections & Buffer zone / belt \\
\hline Higher & & & & 1 \\
\hline Lower & & & & \\
\hline
\end{tabular}

\section{Planning Land Cover for Adjacent, Surrounding EPA Areas}

It can be difficult to evaluate the EPA effectiveness in terms of conservation of the biodiversity, ecological integrity, and the lack of a consistent system of measurement of the effectiveness of an EPA [47]. But, it is generally understood that one of the most important actions for protecting the EPA is having control of the surrounding land and preventing or eliminating the edge effect because this represents a stress for the EPA. This is of immediate concern because many EPAs buffer zones usually experience more rapid land cover changes than what was predicted before the creation of the EPA [48]. The result of this is that more a more EPA's are increasing becoming isolated from one another. Depending on the land cover type of the adjacent regions, which is considered as a "buffer zone" of the EPA, the EPA might be structurally and functionally connected to surrounding landscapes [27] (Table I). Land use intensification of the buffer zones might change the ecosystems' multi-functionalities via loss of biological diversity [49].

The above situation is illustrated and validated through the International Union for Conservation Nature and United Nations Environmental Program World Conservation Monitoring Center (IUCN and UNEP-WCMC, respectively) databases [50]. Sixty EPAs around the world with areas larger than $500 \mathrm{~km}^{2}$ were selected at random. The land cover within the buffer zone (300 meters width) of each EPA was visually interpreted through satellite imagery from Google Earth system with the purpose of quantifying land cover patterns within the buffer zones of each EPA. Some examples of the selected EPAs with predominate forest cover were: Kakadu National Park (Australia), Conservation Area Guanacaste (Costa Rica), Iguaçu National Park (Brazil), Virgin Komi Forests (The Russian Federation), and Great 
Smoky Mountains National Park (USA). In brief, the main general findings were: according to the location of the EPA, certain physical features within the buffer zone, including high topographic variability or the presence of a river network, were associated with reduced level of land cover change in the buffer zone. On the other hand, when no physical barriers like the ones mentioned above where present and when "development" already existed within neighboring region of the EPA, the land cover showed higher and significant levels of change.

Creation of a land cover system that incorporates large multi-use belts within the buffer zone surrounding the EPAs may facilitate effective protection of biological diversity while simultaneously supporting intense human settlement on the edge [45]. The land use in the immediate surroundings of the EPA should have the lowest intensity of human use because it has the highest spatial influence on the overall conservation mission. Furthermore, reconstitution of forest belts within the buffer zone that borders the EPA would help increase forest area. The urban land and road networks should be minimized (if not avoided) within the buffer zone. Prioritizing the rural land use seems to be the best alternative, especially if "soft" land management practices, for example, organic agriculture, are adopted by local rural landowners.

Here a suggestion is presented for rural properties located in the border region of EPAs. Within the EPA buffer region, areas located up to 300 meters from farms should consider establishing or protecting any existing forests. This region would be maintained as a "back garden forest" (Fig. 1). If the area is deforested, re-vegetation activities should be highly encouraged. In terms of education, the famous phrase "Not in my back yard" should be changed to the phrase "Yes in my back yard". The transition from this forested range to the EPA should not be fenced to allow the transit and natural migration of wild animals. If re-vegetation activity is needed, it is recommended to consider the principle of the passive restoration or spontaneous colonization or consider the use of nucleation techniques with rigorous control and elimination of exotic species [23].

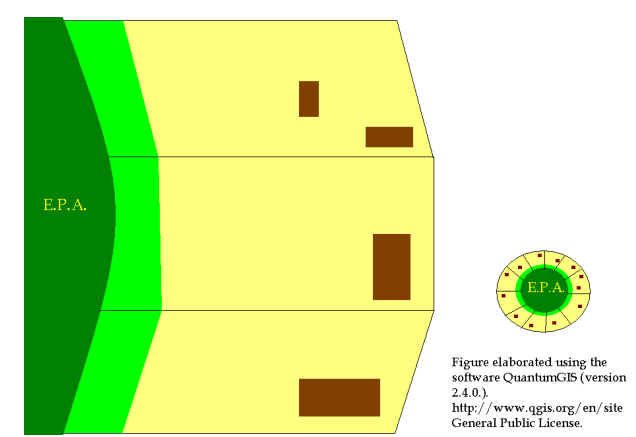

Fig. 1. Proposal for territorial organization of rural properties adjacent to Environmental Protected Area (EPA, in dark green).

The inset figure shows a general view of an EPA surrounded by rural properties. In the larger figure, the EPA is displayed in dark green with the territorial organization of each rural property shown in soft green, yellow and brown. The polygons delineated by black lines are the limits of each property. They could be either fenced or not. In each rural property, the portion filled with soft green corresponds to the "forested back garden" and the frontier between the forested back garden and the EPA should not be fenced to favor the transition of wildlife. In the yellowed parts of each rural property agricultural activities might be practiced in special organic agriculture. Brown squares or rectangles: they are the house of the landowners.

In terms of economic value, harvesting non-timber and non-wood forest products should be permitted in the buffer region of the EPA as well as incorporating less intensive ecotourism activities. The ideal location for agroforestry activities should be from the $300 \mathrm{~m}$ zone to the front of the property, yet these activities should still consider using sustainable management practices. Using only native species in these agroforestry regions would further help promote local biodiversity. The highest intensities of land use should be completely avoided within the buffer zone. For example, extraction of any mineral material should be strictly prohibited to a buffer of at least $10 \mathrm{~km}$ from the EPA. In this "frontier", a fence could be installed to avoid the invasion of livestock and other domestic animals, e.g. dogs, into forested areas, or invasion of wild animals into non-forested areas. Further, the forested buffer should play the role of protecting the EPA by filtering the invasion of non-native species.

\section{E. Improvement of the Governance of Land Use}

Land use planning regulations and land management policies suggested above are feasible and could be established and integrated by governments with different cultural values and practices. Future deforestation lies not with the location of existing farms, but instead, it hinges on where future farms will be established or where farming land practices will be expanding [21]. The land use planning and the land cover change monitoring should be established and monitored by all governmental spheres, but the design of land management strategies should be developed principally at the municipal or community level. Actions aiming to control the process of migration, especially rural migration into buffer zone areas, should be prioritized.

An efficient land use information system should be established by an agency or minister at the national government level and the forest information and databased systems should be shared with other institutions across all relevant governmental spheres. Because the level of bureaucracy is generally not as complex at the municipal or community level; there is the possibility for meaningful political negotiations to occur that involve the local community and that create a participatory management plan [51].

At the municipal level, the establishment of voluntary pacts among the municipal authorities and local community leaders may be facilitated. Such municipal official and leaders usually live within the region and are familiar with local environmental concerns. In some regions, such as in Mexico, India, Argentina, and Brazil, regional community-based forest management has been demonstrated to have had an effective role in forest conservation [52], [53].

\section{F. The Green Nudge Principle}

The suggestions presented above regarding establishing guidelines for sustainable land use management would not be effective without the commitment of individual citizens. An important factor in mitigating deforestation is to encourage or to continue to promote a sustainable mind-set. This involves 
research into the social psychology of land use management. The point is that it is much easier to preserve a forest ecosystem if there is a more favorable view of the forest's intrinsic value at both the societal level and the individual level. This social psychology approach might help to diminish or interrupt the process of deforestation and other modalities of environmental degradations because people behave and react differently from environmental concerns [54].

It has been demonstrated from the academic literature that when people are asked to talk or to do something, their opinions, actions or choices vary according to the opinions of their colleagues and social circles. The disapproval from others or not wanting to be out of line with their peers does have a negative effect on the brain [55]. Thus, because a single person can intentionally alter a pristine forest through conversion of land to agriculture and through the introduction of exotic species [56], the importance of how people view the forest cannot be overstated.

In order to help to reverse deforestation, there is a psychology-based alternative or intervention called the "Green Nudge". A Green Nudge is a subtle method of promoting environmentally responsible behavior without offering material incentives or imposing penalties. It uses several behavioral approaches, such as compliance with social rules or inertia to encourage citizens to adopt lifestyles with a more responsible impact on the environment.

Several locations would be well-suited to Green Nudges, and other locations are already using Green Nudges. Green Nudges exist, such as paper-saving, reducing the number of plastic bags, recycling waste, energy-saving, water-saving, clean streets are examples [57]. However, most of Green Nudge approaches in existence seem to be intended for urban people. It is believed that this same approach would also be successful for rural people as well.

The media might be beneficial for communicating and promoting Green Nudges. One important advantage is that, somehow, people will be inspired with the information no matter where they are. The dissemination of this information routinely in the television or radio programs or on internet (social webs, for example) or ads in newspapers and magazines could be supported at the government level through tax breaks and granting agencies. Religious institutions can also be instrumental with the Green Nudge approach. Hence the Green Nudge may be an important strategy for facilitating interdisciplinary cooperation of ideas associated with the social and environmental complexities of sustainability.

The Green Nudge is applicable even within countries where afforestation is occurring at a national level because deforestation is still probably occurring at some level. The forests operational policy approved in 2002 by the Executive Board of Directors of the World Bank, supports that all forests should be included, not only the tropical forests [9]. Hence, it is important that all countries promote green nudge activities. The key focus area here is making Green Nudges that: (1) promote more positive attitudes toward the forests, and (2) act toward the preservation of the remaining natural places by eliminating the degrading factors [54].

The use of smartphones for disseminating Green Nudges might also be an option. In 2012, $78 \%$ of the world population held any cell phone device [9]. Another advantage is the kind of information that can be transmitted according to the socio-economic scenario of the place. In general, activities should be aimed to prevent the opening of forested areas and encourage their conservation; prevent hunting and wildlife trade; control the factors of environmental degradation and threats to biodiversity; increasing the sense of environmental responsibility. Of course that actions aiming change the pattern of overconsumption (whatever the product, including water and energy) and adoption of new attitudes, as exigencies for environmental friendly timbers, will have many kinds of benefits, including the diminution of the demand for forest-based products.

\section{CONClUSIONS AND PERSPECTIVES}

World deforestation continues at an alarmingly high rate. Although the natural and ecological patterns of forests do not consider political boundaries, the loss of forested areas is strongly related to human features. The kinds and intensities of actions responsible for the loss of forested areas are spatially heterogeneous, and they are normally a result of multifaceted interactions of social and politic factors.

Aiming to maintain ecosystems services provided by the forests, currently, there are two options: conserving the remaining forests and restore the degraded forest areas. Stopping deforestation and conserving the remaining forests is one of the pillars to reaching the sustainable development.

Strategies for stopping deforestation have been postulated and they should be applied at multiple spatial, social, and political scales. The principle "Think globally and act locally" should be an underlining and universal theme. Concerted efforts to improve upon existing land management practices, implementation and enforcement of sound environmental policies, establishing more functional ecological preserves, employing more sustainable agricultural practices within buffer zones that abut forests, and promoting a Green Nudge philosophy to encourage a more positive view of forests, would help reduce deforestation, and would ultimately improve the quality of both forests ecosystems and human societies at a global scale.

\section{REFERENCES}

[1] S. Chakravartyet et al., Deforestation: Causes, Effects, and Control Strategies, 2012, pp. 978-953.

[2] R. L. Chazdon, "Beyond deforestation: restoring forests and ecosystem services on degraded lands," Science, vol. 320, pp. 1458-1460, 2008.

[3] P. M. Fearnside, "The roles and movements of actors in the deforestation of Brazilian Amazonia," Ecol. Soc., vol. 13, 23-44, 2008.

[4] R. A. Matthew, Global Environmental Change and Human Security, MIP Press, 2010

[5] N. S. Sodhi, "Tropical biodiversity loss and people: A brief review," Basic App. Ecol., vol. 9, pp. 93-99, 2008.

[6] P. Meyfroidt and E. F. Lambin, "Forest transition in Vietnam and displacement of deforestation abroad," P. Natl. Acad. Sci. USA, vol. 106, pp. 16139-16144, 2009

[7] V. S. Negi, R. K. Maikhuri, and L. S. Rawat, "Non-timber forest products (NTFPs): A viable option for biodiversity conservation and livelihood enhancement in central Himalaya," Biodiv. Conserv., vol. 20, pp. 545-559, 2011.

[8] C. A. Okia, Global Perspectives on Sustainable Forest Management, (IntechOpen), 2012 
[9] World Bank. (2012). World Bank Open Data. [Online]. Available: http://data.worldbank.org

[10] United Nations. (2011). International Year of Forests. [Online]. Available: www.un.org/forests

[11] L. Gibson et al., "Primary forests are irreplaceable for sustaining tropical biodiversity," Nature, vol. 478, pp. 378-383, 2011.

[12] P. Potapov et al., "Mapping the world's intact forest landscapes by remote sensing," Ecol. Soc., vol. 13, pp. 51-66, 2008.

[13] B. Fisher, R. K. Turner, and P. Morling, "Defining and classifying ecosystem services for decision making," Ecol. Econ., vol. 68, pp. 643-653, 2009.

[14] F. T. Vries et al., "Land use alters the resistance and resilience of soil food webs to drought," Nature Climate Change, vol. 2, pp. 276-280, 2012.

[15] M. A. Palmer et al., "Ecology for a crowded planet," Science, vol. 304 pp. 1252-1253, 2004.

[16] FAO - Food and Agriculture Organization. (2012). State of World's Forests. [Online].

Available: http://www.fao.org/docrep/016/i3010e/i3010e00.htm

[17] J. Oglethorpe et al., People on the Move, World Wildlife Fund, 2007.

[18] S. A. Laird, "The interweave of people and place: Biocultural diversity in migrant and indigenous livelihoods around Mount Cameroon," Int. Forestry. Rev., vol. 13, pp. 275-293, 2011.

[19] G. Muriuki, "The role of squatters in retention of native vegetation: A case study of the Chyulu Hills, Kenya," App. Geogr., vol. 31, pp. $577-589,2011$

[20] D. Carr, "Rural migration: The driving force behind tropical deforestation on the settlement frontier," Progr. Hum. Geog., vol. 33, pp. $355-378,2009$.

[21] G. S. Amacher, E. Koskela, and M. Ollikainen, "Deforestation and land use under insecure property rights," Environ. Dev. Econ., vol. 14, pp. 281-303, 2008

[22] G. I. Diaz et al., "Drivers of land abandonment in Southern Chile and implications for landscape planning," Landscape Urban Plan., vol. 99, pp. 207-217, 2011.

[23] R. J. Hobbs, E. Higgs, and J. A. Harris, "Novel ecosystems: Implications for conservation and restoration," Trends Ecol.Evol., vol. 24, pp. 599-605, 2009.

[24] D. Nepstad, C. M. Stickler, and O. T. Almeida, "Globalization of the Amazon soy and beef industries: opportunities for conservation," Conserv. Biol., vol. 20, pp. 1595-1603, 2006.

[25] T. K. Rudel, R. Defries, and G. P. Asner, "Changing drivers of deforestation and new opportunities for conservation," Conserv. Biol., vol. 23, pp. 1396-1405, 2009.

[26] K. Obidzinski et al., "Environmental and social impacts of oil palm plantations and their implications for biofuel production in Indonesia," Ecol. Soc., vol. 17, pp. 25-44, 2012.

[27] R. DeFries, K. K., Karanth, and S. Pareeth, "Interactions between protected areas and their surroundings in human-dominated tropical landscapes," Biol. Conserv., vol. 143, pp. 2870-2880, 2010.

[28] H. Klemick, "Shifting cultivation, forest fallow, and externalities in ecosystem services: Evidence from the Eastern Amazon," J. Environ. Econ. Manage., vol. 61, pp. 95-106, 2011.

[29] J. A. Foley et al., "Global consequences of land use," Science, vol. 309, pp. 570-574, 2005.

[30] N. B. Grimm et al., "Global change and the ecology of cities," Science, vol. 319, pp. 756-760, 2008.

[31] G. Benítez et al., "Urban expansion and the environmental effects of informal settlements on the outskirts of Xalapa city, Veracruz, Mexico," Environ. Urban., vol. 24, pp. 149-166, 2012.

[32] A. W. Coffin, "From road kill to road ecology: A review of the ecological effects of roads," J. Transp. Geogr., vol. 15, pp. 396-406, 2007.

[33] W. F. Laurance, J. Sayer, and K. G. Cassman, "Agricultural expansion and its impacts on tropical nature," Trends Ecol. Evol., vol. 29, pp. 107-116, 2014

[34] M. E. Newman, K. P., McLaren, and B. S. Wilson, "Assessing deforestation and fragmentation in a tropical moist forest over 68 years; the impact of roads and legal protection in the Cockpit Country, Jamaica," Forest Ecol. Manage., vol. 315, pp. 138-152, 2014.

[35] W. F. Laurance et al., "Predatory corporations, failing governance, and the fate of forests in Papua New Guinea," Conserv. Lett., vol. 4, pp. 95-100, 2011.

[36] V. H. Dale et al., "Ecological principles and guidelines for managing the use of land," Ecol. App., vol. 10, pp. 639-670, 2000.

[37] M. C. Bottrill, and R. L. Pressey, "The effectiveness and evaluation of conservation planning," Conserv. Lett., vol. 5, pp. 407-420, 2012.
[38] ITTO (International Tropical Timber Organization). (2010). Annual Review and Assessment of the World Timber Situation. [Online]. Available: http://www.itto.int

[39] J. Chen et al., "The efficacy of forest certification: Perceptions of Canadian forest products retailers," Forest Chron., vol. 87, pp. 636-643, 2011.

[40] J. Ebeling, and M. Yasué, "The effectiveness of marked-based conservation in the tropics: forest certification in Ecuador and Bolivia," J. Environ. Manage., vol. 90, pp. 1145-1153, 2009.

[41] A. Acebey et al., "Ecoregional distribution of potentially useful species of Araceae and Bromeliaceae as non-timber forest products in Bolivia," Biodivers. Conserv., vol. 19, pp. 2553-2564, 2010.

[42] F. G. Vodouhê et al., "Estimating the local value of non-timber forest products to Pendjari Biosphere Reserve Dwellers in Benin," Econ. Bot., vol. 63, pp. 397-412, 2009.

[43] B. J. Lausche, and F. Burhenne-Guilmin, Guidelines for Protected Areas Legislation, The International Union for Conservation Nature, 2011.

[44] O. Venter et al., "Targeting global protected area expansion for imperiled biodiversity," PLoS Biology, vol. 12, p. e1001891, 2014.

[45] G. Wittemyer et al., "Accelerated human population growth at protected area edges," Science, vol. 321, pp. 123-126, 2008

[46] W. J. Ripple et al., "Status and ecological effects of the world's largest carnivores," Science, vol. 343, pp. 151-163, 2014.

[47] L. Naughton-Treves, M. B. Holland, and K. Brandon, "The role of protected areas in conserving biodiversity and sustaining local livelihoods," Апnи. Rev. Environ. Res., vol. 30, pp. 219-52, 2005.

[48] C. Davis "Trajectories of land use change around U.S. National Parks and challenges and opportunities for management," Ecol. App., vol. 21, pp. 3299-3316, 2011.

[49] E. Allan et al., "Land use intensification alters ecosystem multifunctionality via loss of biodiversity and changes to the functional composition," Ecol. Lett., vol. 18, pp. 834-843, 2015.

[50] IUCN-UNEP (The International Union for Conservation Nature and United Nations Environmental Program - World Conservation Monitoring Center). (2012). The World Database on Protected Areas. [Online]. Available: www.protectedplanet.net

[51] I. B. Lima and L. Buszynski, "Local environmental governance, public policies and deforestation in Amazonia," Manage. Environ. Qual., vol. 22, pp. 292-316, 2011.

[52] P. P. Singh, "Exploring biodiversity and climate change benefits of community-based forest management," Global Environ. Chang., vol. 18 , pp. 468-478, 2008.

[53] S. Humphries et al., "Are community-based forest enterprises in the tropics financially viable? Case studies from the Brazilian Amazon," Ecol. Econ., vol. 77, pp. 62-73, 2012.

[54] L. C. Planas, Finding a Green Nudge: Moral Motivation and Green Behavior, 2013

[55] G. Webster. (2012). Is a 'Nudge' in the Right Direction All We Need to Be Greener? [Online]. Available: http://edition.cnn.com/2012/02/08/tech/innovation/green-nudge-envir onment-persuasion

[56] E. C. Ellis, "Anthropogenic transformation of the terrestrial biosphere," Philos. T. R. Soc. - A, vol. 369, pp. 1010-1035, 2011.

[57] CAS - Centre d'analyse stratégique, Green Nudges: New Incentives for Ecological Behavior, 2012

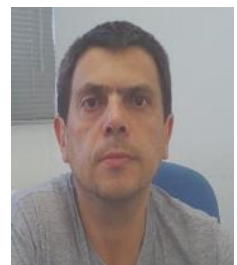

Alexandre Marco da Silva is adjunct professor, the Department of Environmental Engineering; Institute of Science and Technology of Sorocaba, São Paulo State University (UNESP), Brazil. He got the B.S. in ecology, São Paulo State University, Rio Claro-SP, 1989-1993; the M.S. sciences of environmental engineering, São Paulo University, São Carlos-SP, 1993-1997; the PhD sciences of environmental engineering, São Paulo University, São Carlos-SP, 1997-1999. His research interests are conservation of natural resources, restoration ecology, geographic information systems applied to environmental engineering.

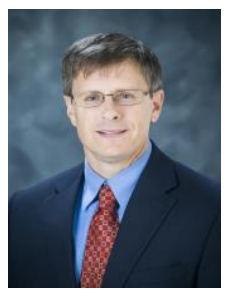

John Rodgers is professor, the Department of Geosciences, Mississippi State University, USA. He got the B.S. in biology and botany, University of Tennessee, Knoxville, 1987-1991; the M.S. from the Department of Botany, University of Tennessee, Knoxville, 1991-1994; the Ph.D. from the Department of Geography, University of Georgia, 1994-1999. His research interests are invasive species, coastal processes, geographic information systems. 